UDC $664 ; 66.06$

\title{
INTRODUCTION AND NEUTRALIZATION OF RADIONUCLIDES INTO MAGNETO- CONTROLLED MINERALMATRICES BASED ON CENOSPHERES OF ENERGETICAL ASHES
}

\author{
V.S.Yemelyanova, Y.Zh.Aibasov, E.M.Shakiyev, B.B.Baizhomartov \\ Research Institute of New Chemical Technologies and Materials, \\ 480012, Almaty, Republic of Kazakhstan, e-mail:niinhtm@mail.ru
}

\begin{abstract}
The use of magneto-controlled sorbents based on cenospheres of energy ashes for solidification of liquid radioactive waste (RAW) will enable to concentrate $R A W$ oxides in the matrix volume up to 30-40 mass \%, to reduce the volume of liquid waste from 5-20 times (porous matrix) up to 1500 times (sorbents), as well as to transfer liquid RAW to the stable mineral-like matrices (pollucite, Srfeldspar, nepheline and their compositions) fit for long-term dumping in geological formations through implementation of energy-saving processes that need no temperatures above $1100{ }^{\circ} \mathrm{C}$.

Keywords: energetical ashes, sorbent, radioactive waste, radionuclide
\end{abstract}

\section{Introduction}

According to the documents of the IAEA, strategy for safe handling of all types of radioactive waste is to minimize them, i.e. reduce the amount of waste and decelerate their activity. It is preferable to focus on the concentration (evaporation, ion exchange, and sorption) and retention processes by localization of radionuclides within the waste matrix or packaging and isolation them from the biosphere available to a human (bituminization, cementing, incorporation into polymers, glass, ceramics, glass-metal compositions, synthetic minerals) instead of their dilution and dispersion. The complexity of the problem lies in the fact that at present the existing technology doesn't allow us to completely neutralize them, i.e. to turn into a non-radioactive substance. This cannot be achieved by any chemical or physical methods available. It is believed that even if the nuclear transmutation full transfer of radioactive isotopes to the stable one is impossible, at least, because the composition of the radioactive waste is complex, and it is impossible to choose conditions for the transmutation of all radionuclides. Currently, intensive research is underway in many countries to develop effective methods of radioactive waste control. As progress is achieved in the research into low-energy nuclear transmutation of chemical elements, there is a probable formulation of the question of complete decontamination of radioactive waste [1-2]. Results of experimental and theoretical studies carried out by a group of Russian scientists afford us to hope that the open method of electromagnetic exposure conformably to radioactive materials leads to the transition of unstable isotopes into the stable ones. Moreover, such a process of transmutation is not accompanied by concomitant release of ionizing radiation. It found that low-energy transmutation is the threshold response of the resonant nature and exothermic as well which makes it energetically favorable.

We have shown in this paper the promising applications of magneto-controlled hollow aluminosilicate microspheres of volatile energy ashes obtained from aluminosilicate melt of the mineral part of coals in case of pulverized combustion and accessible renewable aluminosilicate raw materials with an annual production capacity of 100,000 tons in Russia only. 


\section{Experimental results and discussion}

As a raw material, there is used a certain fraction of cenospheres, particle size of 20-250 $\mathrm{mm}$, a bulk density of $350 \mathrm{~g} / \mathrm{cm}^{3}$ and a specific surface area of $12.5 \mathrm{~m}^{2} / \mathrm{g}$ which was isolated from the concentrate of cenospheres of fly ashes of burning coal from Ekibastuz field in Kazakhstan at the thermal power plant in Almaty city. For fractionation and stabilization of the composition of cenospheres obtained from fly ash of coal combustion there was used a column pulsating apparatus with pneumatic pulsators and swirl baffles. The rate of upward flow of water and the amplitude and frequency of pulsation was kept to comply with faction dimensions. At the bottom of the column, there is located an annular electromagnet providing a required range of magnetic field intensity in the cross section upstream. The process efficiency was estimated according to the results of x-ray phase analysis and visual quality control of selected products using electron microscope. The chemical composition of the initial cenospheres were as follows: mass $\% \mathrm{SiO}_{2}-$ 59.73; $\mathrm{Al}_{2} \mathrm{O}_{3}-26.41 ; \mathrm{Fe}_{2} \mathrm{O}_{3}-5.51 ; \mathrm{CaO}-$ 2.15; $\mathrm{TiO}_{2}-1.19 ; \mathrm{Na}_{2} \mathrm{O}-0.82 ; \mathrm{S}-0.87 ; \mathrm{P}-$ 0.539. According to quantitative XRD analysis, the phase composition is represented mainly by quartz and mullite.
Mossbauer' research into cenospheres showed that in the cenospheres containing more than 7 mass $\% \mathrm{Fe}_{2} \mathrm{O}_{3}$ the iron is involved in two phases - the defective magnetite $(67 \%)$ and the phase with parameters close to the disordered orthosilicate of monticellite $(\mathrm{Ca}$, $\mathrm{Mg}, \mathrm{Fe})_{2} \mathrm{SiO}_{4}(33 \%)$. Note that the defective magnetite at room temperature is two equally populated magnetic states - ferromagnetic and superparamagnetic. Sublattice of magnetite is diluted with diamagnetic substitution. The diamagnetic dilution and small size spinel formations result in the superparamagnetic state and the destruction of the fast electronic exchange between $\mathrm{Fe}^{3+}$ and $\mathrm{Fe}^{2+}$ ions in the $B$ sublattice of magnetite.

Cenospheres with a lower concentration of $\mathrm{Fe}_{2} \mathrm{O}_{3}$ (3-4 mass \%) contain iron in spinel (47 $\%)$ and orthosilicate $(53 \%)$. Spinel is paramagnetic at room temperature. In the silicate, the iron is in the divalent state occupying an octahedral M2-type position.

Modified aluminosilicate sorbents are also tested in the process of adsorption of $\mathrm{U}^{6+}$ from productive solutions LLP JV "Betpak-Dala" (Kazakhstan). The test results are shown in Tables 1, 2 and Figure 1.

Table 1. Results of laboratory tests of modified aluminosilicate sorbents

\begin{tabular}{|c|c|c|c|c|c|}
\hline № & $\begin{array}{c}\text { Number of } \\
\text { microspheres, } \mathrm{g}\end{array}$ & Sample volume, $\mathrm{mL}$ & Redoxpotential, $\mathrm{mV}$ & $\mathrm{pH}$ & $\mathrm{U}^{+6}, \mathrm{~g} / \mathrm{L}$ \\
\hline 1. & - & 50 & 407 & 2,20 & 64 \\
\hline 2. & 5,0 & 50 & 291 & 3,47 & 35 \\
\hline 3. & 5,0 & 100 & 280 & 3,58 & 40 \\
\hline 4. & 5,0 & 150 & 273 & 3,71 & 27 \\
\hline
\end{tabular}

Table 2. Results of elemental analysis of the modified microsphere sorbent after passing through productive solution

\begin{tabular}{|c|c|c|c|c|c|c|c|c|c|c|}
\hline Comp. & $\mathrm{Mg}$ & $\mathrm{Si}$ & $\mathrm{P}$ & $\mathrm{Cl}$ & $\mathrm{K}$ & $\mathrm{Ca}$ & $\mathrm{Cr}$ & $\mathrm{Mn}$ & $\mathrm{Fe}$ & $\mathrm{Cu}$ \\
\hline Conc. $\%$ & 0.018 & 18.21 & 0.641 & 3.151 & 2.017 & 3.725 & 0.02 & 0.206 & 11.808 & 0.04 \\
\hline Comp. & $\mathrm{Zn}$ & $\mathrm{Sr}$ & $\mathrm{Pd}$ & $\mathrm{In}$ & $\mathrm{Eu}$ & $\mathrm{Yb}$ & $\mathrm{Re}$ & $\mathrm{Ir}$ & $\mathrm{Pb}$ & $\mathrm{U}$ \\
\hline Conc. $\%$ & 0.039 & 0.215 & 0.071 & 0.545 & 0.088 & 0.006 & 0.005 & 0.009 & 0.042 & 59.141 \\
\hline
\end{tabular}




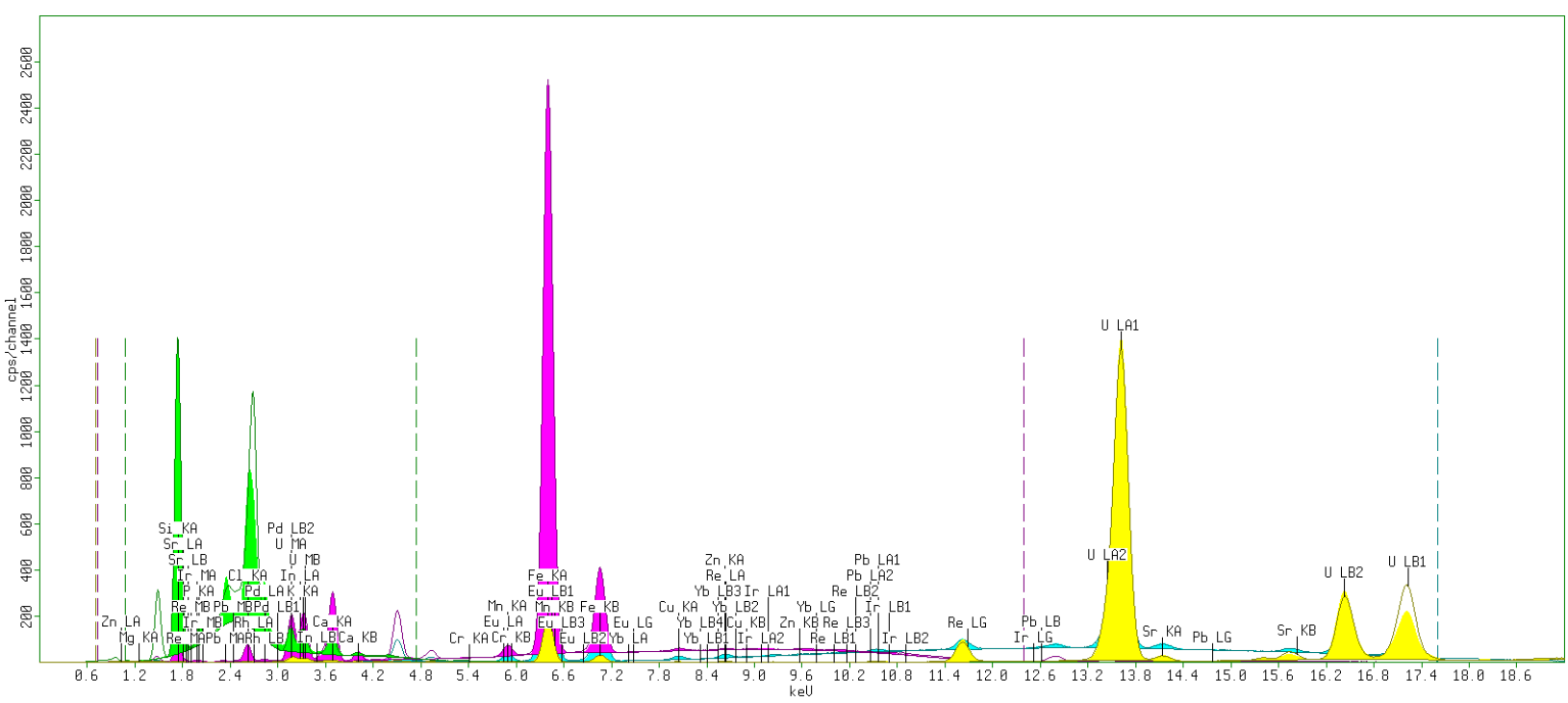

Fig. 1. XRD pattern of modified microsphere aluminosilicate sorbent after passing through productive uranium-containing solution

The obtained results show that the modified aluminosilicate microspheres selected from fly ash TPP-2, Almaty, can be used for sorption of uranium.

Curing $\mathrm{Cs}(\mathrm{Na})$-containing solutions in researching into the phase composition of the composites was carried out using model nitric acid solutions of sodium and cesium as imitators of radioactive ${ }^{137} \mathrm{Cs}$-containing solutions of high-salt regenerators of reextracted cesium or residues of nuclear power plants.

Table 3. Physical and chemical characteristics of initial samples of narrow fractions of cenospheres, as well as the number of related mineral-like phases in cenosphere-salt $\left(\mathrm{CsNO}_{3} / \mathrm{Sr}\left(\mathrm{NO}_{3}\right)_{2}\right)$ compositions

\begin{tabular}{|c|c|c|c|c|c|c|c|c|c|c|c|c|c|c|}
\hline \multirow{2}{*}{$\begin{array}{l}\text { No. of } \\
\text { sample, } \\
\text { mm }\end{array}$} & \multicolumn{4}{|c|}{$\begin{array}{c}\text { Chemical composition, } \mathrm{m} \\
\text { ass } \%\end{array}$} & \multirow{2}{*}{ 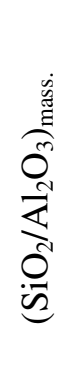 } & \multicolumn{4}{|c|}{$\begin{array}{l}\text { Phase composition } \\
\text { according to XRF, } \\
\text { mass } \%\end{array}$} & \multicolumn{2}{|c|}{$\begin{array}{l}\text { Contents of } \\
\text { introduced } \\
\text { oxides, } \\
\text { mass \% }\end{array}$} & \multicolumn{3}{|c|}{$\begin{array}{c}\text { Theoretical } \\
\text { phase content, } \\
\text { mass } \%\end{array}$} \\
\hline & $\overbrace{n=1}^{N}$ & 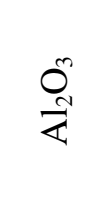 & 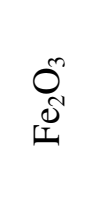 & 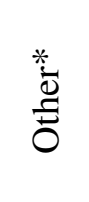 & & $\stackrel{\stackrel{N}{\vec{Z}}}{\vec{\Xi}}$ & $\frac{\frac{\pi}{0}}{\frac{\pi}{\pi}}$ & $\stackrel{\stackrel{\mathscr{\Xi}}{\Xi}}{\stackrel{\Xi}{\Xi}}$ & 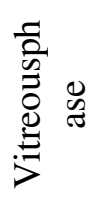 & vin & $\stackrel{0}{i}$ & $\begin{array}{l}\stackrel{\frac{9}{0}}{\Xi} \\
\frac{0}{0} \\
2\end{array}$ & $\begin{array}{l}\frac{\pi}{0} \\
\frac{0}{0} \\
\frac{0}{0} \\
\frac{1}{1} \\
v\end{array}$ & $\begin{array}{l}\frac{\vec{z}}{2} \\
\frac{0}{0} \\
\frac{0}{2} \\
\frac{1}{1}\end{array}$ \\
\hline 1 & 66.36 & 19.6 & 6.44 & 6.86 & 3.4 & 5.9 & 0.4 & 1.5 & 92.2 & 35 & - & - & 90 & - \\
\hline 2 & 57.29 & 37.04 & 4.82 & 0.6 & 1.5 & 2.5 & 0.1 & 39.1 & 58.3 & 40.1 & - & 89 & - & 86 \\
\hline
\end{tabular}



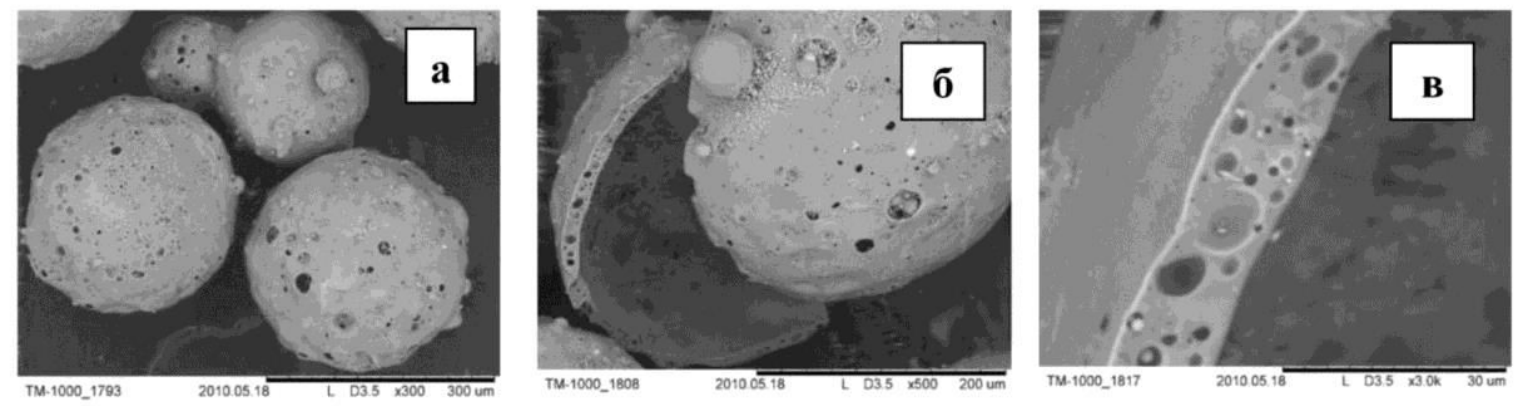

Figure 2. Perforated cenospheres from fly ashes through the combustion of Kuznetsk coal, fraction +0.5-0.25 mm: (a) general view, (b) destroyed cenosphere, (c) wall's structure on the chip

The precursors were prepared by mixing cenospheres with a solution $\mathrm{CsNO}_{3} / \mathrm{Sr}\left(\mathrm{NO}_{3}\right)_{2}$ at a predetermined ratio, followed by removing moisture during the drying process at temperatures $80-120{ }^{\circ} \mathrm{C}$. The number of $\mathrm{CsNO}_{3}, \quad\left(\mathrm{Cs}_{2} \mathrm{O}\right) / \mathrm{Sr}\left(\mathrm{NO}_{3}\right)_{2}, \quad(\mathrm{SrO}) \quad$ were introduced with an emphasis on obtaining the compound with maximum possible content of the target phase for this composition of cenospheres $\left(\mathrm{SiO}_{2} / \mathrm{Al}_{2} \mathrm{O}_{3}\right) \quad$ (Table 3). Researchers obtained cenosphere-salt compositions based on narrow fractions of cenospheres with those close to stoichiometric $\left(35 \% \mathrm{Cs}_{2} \mathrm{O}\right.$ and $27.8 \% \mathrm{SrO}$ ), of which theoretically can be generated 90 mass $\%$ of Cs-feldspar, 89 mass \% of pollucite and 86 mass \% of Sr-feldspar.

Thermogram for analyzed samples of cenosphere-salt compositions indicates that there are three endothermic effects: the first with a maximum ranging from 153 to $155^{\circ} \mathrm{C}$ is associated with polymorphic hexagonalcubic transition in cesium nitrate; the second with a maximum at $403-405{ }^{\circ} \mathrm{C}$ due to the melting of cesium nitrate; the third where 752$778{ }^{\circ} \mathrm{C}$ correspond to the decomposition of cesium nitrate and is accompanied by significant mass loss. Starting with $850{ }^{\circ} \mathrm{C}$ there is a slight weight reduction possibly due to volatilization of cesium oxide $(0.39 \%)$. At temperatures above $900{ }^{\circ} \mathrm{C}$ there is observed a series of exo-effects with maximum 970-985 ${ }^{\circ} \mathrm{C}$, which apparently conforms to the formation of new crystalline phases.

It can be assumed that the crystallization process involving oxide of cesium occurs at temperatures above $750{ }^{\circ} \mathrm{C}$. Proceeding from the results obtained, temperatures of 750,900 and $1000{ }^{\circ} \mathrm{C}$ were selected to treat cenospheresalt compositions.

Thus defined thermal conditions of the inclusion of $\mathrm{Cs}^{+}$into the phase of pollucite during the solid-phase crystallization of precursors on the basis of cenosphere-salt $\left(\mathrm{CsNO}_{3}\right)$ compositions and the data obtained on the phase composition of the products of crystallization cenosphere-salt $\left(\mathrm{CsNO}_{3}\right)$ $\left.\mathrm{Sr}\left(\mathrm{NO}_{3}\right)_{2}\right)$ compositions. It revealed that the solid-phase crystallization process of cenosphere-salt compositions of pollucite's is theoretically possible yield of mineral-like phases.

To examine the effect of the magnetic field, the resulting micro-spherical aluminosilicate composites were placed in the center of the solenoid with constant magnetic field intensity of $28.5 \mathrm{kA} / \mathrm{m}$. It found that the superposition of the external magnetic field leads to a rapid saturation of the magnetization in the weak and medium magnetic fields. This is probably due to the fact that the total magnetic moment of the nano-composite may be tens or hundreds times greater than the magnetic moments of individual atoms. As a result, factors of volume, surface forces and torque moments are involved in the structure of the nano-composite that can be modeled and applied in the creation of controlled movements.

It was discovered that irradiation of aluminosilicate composite in the magnetic field leads to the increase by 30-40 \% adsorption of uranium and the rise in the retention factor of the isotope ${ }^{238} \mathrm{U}$ of up to 56 $\%$. The first positive experiments on neutralization of radionuclides in the presence 
of cheap magnetically controlled magnetic reactor under the influence of certain aluminosilicate composites, and, most frequency electromagnetic radiation, importantly, the experience of Russian amplitude and topology. We hope to get scientists that prompted us to purchase the successful results in the nearest future. device and continue studies at the vortex

\section{REFERENCES}

1. Kuznetsov V.D., Mishinsky G.V., Penkov F.M., Arbuzov V.I., Zhemenik V.I. Low Energy Transmutation of Atomic Nuclei of Chemical Elements. Journal Annales de la Fondation Louis de Broglie. 2003, vol.28, no.2. Web-site: http://FondationLousdeBroglie.org

2. Rodionov B.U. Cold multinuclear reactions. In: Materials of the $11^{\text {th }}$ Russian conference on cold transmutation of nuclei of chemical elements. Moscow. 2004, p.189-197.

\section{ВНЕДРЕНИЕ И НЕЙТРАЛИЗАЦИЯ РАДИОНУКЛИДОВ В МАГНИТОУПРАВЛЯЕМЫЕ МИНЕРАЛЬНЫЕ МАТРИЦЫ НА ОСНОВЕ ЦЕНОСФЕР ЭНЕРГЕТИЧЕСКИХ ЗОЛ}

\section{В.С.Емельянова, Е.Ж.Айбасов, Э.М.Шакиев, Б.Б.Байжомартов}

Научно-исследовательский институт новых химических технологий и материалов 480012, Алматы,, Республика Казахстан, е-таil:niinhtm@таil.ru

Использование магнитоуправляемых сорбентов на основе изеносфер энергетических зол для отверждения жидких радиоактивных отходов позволит сконцентрировать окисльи радиоактивных отходов в объеме матрицы до 30-40 масс. \%, сократить объем жидких отходов с 5-20 раз (пористая матрища) до 1500 раз (сорбенты), а также перевести жидкие радиоактивные отходы в стабильные минералоподобные матрицы (поллюиит, Sr-nолевой шпат, нефелин и их композиции), пригодные для длительного захоронения в геологических формачиях, посредством реализачии энергосберегающих прочессов, которые не требуют температур выше $1100{ }^{\circ} \mathrm{C}$.

Ключевые слова: энергетическая зола, сорбент, радиоактивные отходы, радионуклид.

Поступила в редакиию 29.10.2016. 